\title{
Turfgrass Renovation Using Dazomet to Control the Poa annua L. Soil Seed Bank
}

\author{
Bruce E. Branham, ${ }^{1}$ Glenn A. Hardebeck, ${ }^{2}$ Joseph W. Meyer, ${ }^{1}$ and \\ Zachary J. Reicher ${ }^{2}$ \\ Dept. of Natural Resources and Environmental Sciences, University of Illinois, \\ Urbana, Il 61801
}

\section{Additional index words. annual bluegrass, soil sterilization, establishment, creeping bentgrass}

\begin{abstract}
Annual bluegrass (Poa annua $\mathrm{L}_{\text {.) }}$ is an invasive weed producing copious amounts of viable seed that compete with seedling turfgrasses during renovation. These field studies were conducted to determine the effectiveness of dazomet (tetrahydro-3,5-dimethyl-2H-1,3,5thiadiazine-2-thione), a granular soil sterilant that breaks down in soil to release methyl isothiocyanate (MITC), for controlling the soil seed bank of annual bluegrass during turfgrass renovation. Field trials in Urbana, Ill., and West Lafayette, Ind., in Spring and Fall 2000 and 2001 evaluated dazomet rate from 0 to $504 \mathrm{~kg}^{\circ} \mathrm{ha}^{-1}$ and soil preparation techniques to determine the most effective practices to reduce annual bluegrass reestablishment into a creeping bentgrass (Agrostis stolonifera L.) seeding. The interval, in days, between dazomet application and creeping bentgrass planting was also examined to determine the optimal seeding time as measured by the level of annual bluegrass reestablishment. Spring trials generally gave poor results that were attributed to windy conditions resulting in rapid loss of MITC. The annual bluegrass soil seed bank was reduced $46 \%$ in spring trials compared to $78 \%$ in fall trials. Increasing dazomet rates reduced the absolute number of viable annual bluegrass seeds remaining in the soil. However, significant quantities of viable seed remained, regardless of dazomet rate. Annual bluegrass infested the renovated turf in all trials to varying degrees. Dazomet rates of 420 or $504 \mathrm{~kg} \cdot \mathrm{ha}^{-1}$ yielded the lowest rates of annual bluegrass reestablishment. Trials conducted in the fall at these rates resulted in annual bluegrass cover of $1 \%$ to $20 \%$ in the resulting turf. Creeping bentgrass planted at 1 day after dazomet application had significantly less annual bluegrass than when seeded at 7 or 9 days after dazomet application. Dazomet is a tool that can help reestablish a new turf with lower levels of annual bluegrass. However, eradication of annual bluegrass with dazomet is not likely and environmental conditions will dramatically affect the success of the sterilization.
\end{abstract}

Turfgrass used as an athletic or golf course turf is often plagued with annual bluegrass $(\mathrm{AB})$ invasion (Beard etal., 1978). Frequently, the AB population becomes so significant that turfgrass renovation is attempted to establish more desirable species or cultivars. The most common approach to renovation is to kill existing turf with a non-selective herbicide and reseed with the desired turf species. Unfortunately, these renovations often fail because no attempt is made to control the $\mathrm{AB}$ soil seed bank that can be staggeringly large. Gaussoin et al. (1989) estimated that an AB-infested fairway turf can contain upwards of 104,000 viable $\mathrm{AB}$ seeds $/ \mathrm{m}^{2}$, whereas Lush (1988) estimated that an AB-infested putting green can contain 168,000 viable seeds $/ \mathrm{m}^{2}$. Typical turf seeding rates for fairway turf are 68,000 seeds of creeping bentgrass $/ \mathrm{m}^{2}$ or 23,000 viable seeds $/ \mathrm{m}^{2}$ of kentucky bluegrass (Turgeon, 2002).

\footnotetext{
Received for publication 14 Jan. 2004. Accepted for publication $24 \mathrm{Apr}$. 2004. The authors gratefully acknowledge the financial support provided by BASF Corporation, the Illinois Turfgrass Foundation, and the Midwest Regional Turfgrass Foundation.

${ }^{1}$ To whom reprint requests should be addressed; e-mailbbranham@uiuc.edu.

${ }^{2}$ Dept. of Agronomy, Purdue University, W. Lafayette, IN 47907.
}

Soil sterilization is a logical method for eliminating the $\mathrm{AB}$ soil seed bank. Most soil sterilants are used to control multiple pests within the soil profile of high value crops such as strawberry (Rieger et al., 2002) or tomato (Locascio et al., 1997). Soil sterilants are typically injected or incorporated through tillage to control diseases, weeds, and nematodes within the top $15-20 \mathrm{~cm}$ of the soil profile. Since the bulk of the AB soil seed bank is contained in the surface thatch and mat (Lush, 1988), subsurface incorporation of soil sterilants to control $\mathrm{AB}$ may not be necessary. Soil sterilization is often done on putting greens because of the relatively small acreage involved, but costs can exceed \$2000/ha (Rieger et al., 2001).

Methyl bromide is the soil sterilant of choice for turf managers (Unruh et al., 2002), but the use of methyl bromide is being phased out, and the treated area must be covered with a tarp prior to release of the gas. Covering 0.5 to 1 ha of putting greens with tarp is labor intensive but feasible. However, covering 8 to 12 ha of fairway with tarp would be logistically difficult and is rarely attempted. Alternatives to methyl bromide that do not require coverage with a plastic tarp could be valuable on larger turfgrass acreages. In Florida, Unruh et al. (2002) examined alternatives to methyl bromide for soil sterilization, but concluded that none of the products evaluated, including dazomet, were as effective as methyl bromide. However, their evaluation included a broad spectrum of difficult-to-control weeds found in warm season climates. In the cool-season region of the U.S., $\mathrm{AB}$ is the primary weed problem on golf course turf and often the only reason that soil sterilization is contemplated in this region.

Dazomet is a granular product that decomposes in the presence of soil and water to methyl isothiocynanate (MITC), a gas that is the sterilizing agent (Smelt and Leistra 1974). Dazomet has been used for soil sterilization since the early 1970s (Low, 1974). Dazomet's label recommends a waiting period from 12 to $17 \mathrm{~d}$ between application and reseeding (Anon. 2003). For most commercial turf managers, this interval is too long because the expense of renovation is compounded by lack of revenue during the time turf is unplayable. In contrast to current label restrictions, Park and Landschoot (2003) found that creeping bentgrass could be safely established when seeded as soon as one day after treatment (DAT) with surface-applied dazomet.

Park and Landschoot (2003) showed that dazomet could be surface-applied and provide effective control of $A B$ seed in the soil with or without covering the treated area with plastic tarp. They determined that dazomet rates of 340 and $388 \mathrm{~kg} \cdot \mathrm{ha}^{-1}$ provided $>90 \%$ control of the $\mathrm{AB}$ soil seed bank when surface applied to AB-infested turf without a tarp.

The objective of our study was to further define the suitability of dazomet for surface soil sterilization of AB-infested turfs. Specifically, we attempted to determine the effect of dazomet application rate and method on the $\mathrm{AB}$ soil seed bank, on the reseeding interval for creeping bentgrass, and on the reestablishment of $\mathrm{AB}$ in the newly established turf.

\section{Materials and Methods}

Experiments were conducted in two locations: the Landscape Horticulture Research Center in Urbana, Ill., and the Ackerman Hills GolfCourse on the campus of Purdue University in West Lafayette, Ind. Two experiments were conducted in Fall and Spring 2000 and 2001 at both locations for a total of 16 individual experiments. One experiment was designed to determine the optimum dazomet application rate. A second study examined the effect of different soil preparation techniques when using a single dazomet rate. Soil type in Urbana was a Flanagan silt loam (fine, smectic, mesic Aquertic Argiudoll) with $52 \mathrm{~g} \cdot \mathrm{kg}^{-1}$ organic matter, and $\mathrm{pH}$ 6.5. Soil type at the Indiana location was a Chalmers silt loam (fine, silty, mixed mesic Typic Haplaquoll) with $67 \mathrm{~g} \cdot \mathrm{kg}^{-1}$ organic matter and $\mathrm{pH}$ 6.5. Experiments were initiated on 25 May and 17 Aug. 2000 and 24 May and 13 Aug. 2001 in Illinois, and on 8 May and 16 Aug. 2000 and 23 May and 17 Aug. 2001 in Indiana. Main plot sizes at both locations were $0.9 \times 2.4 \mathrm{~m}$ in $2000,0.9 \times 3.0 \mathrm{~m}$ in May 2001, and $0.9 \times 3.7 \mathrm{~m}$ in August 2001. During the turf establishment phase of the experiments, all plots were mown at a height of $1.2 \mathrm{~cm}$.

Dazomet rate. Dazomet was applied at 0 , 
$140,224,308,392$, or $476 \mathrm{~kg}$ product/ha in May 2000 and at rates of $0,168,252,336$, 420 , or $504 \mathrm{~kg}$ product/ha in August 2000 and May and August 2001. Rates were uniformly raised by $28 \mathrm{~kg}$ a.i./ha following the Spring 2000 trials to permit more accurate application with a drop spreader. Immediately before dazomet application, all plots receiving dazomet were core aerified with one pass of walk-behind aerifier with $1.0-\mathrm{cm}$-diameter tines on $5.0 \mathrm{~cm}$ $\times 5.0$-cm spacing and then cores were broken up with one pass of a power rake.

Soil preparation methods. Dazomet was applied at the label rate of $336 \mathrm{~kg}$ product $/ \mathrm{ha}$ (308 kg.ha $\mathrm{h}^{-1}$ in Spring 2000) and various methods of cultivation and/or rolling were applied. Rolling was eliminated after the Spring 2000 experiments because the technique would be impractical on a large scale and had little effect in our study. Application methods included no soil preparation other than the vertical mowing to prepare the seedbed, aerifying $1 \times$ or $3 \times$ with cores returned before dazomet application, aerifying $1 \times$ or $3 \times$ with cores removed before dazomet application, and aerifying $1 \times$ or $3 \times$ with cores returned after dazomet application.

General experimental procedures. Control plots were treated with glyphosate $(\mathrm{N}-($ phos phonomethyl)glycine) and diquat (6,7-dihydrodipyrido[1,2- $\alpha: 2$ ', 1'-c]pyrazinediium ion) at 2.24 and $0.3 \mathrm{~kg} \cdot \mathrm{ha}^{-1}$, respectively, the day before dazomet application. Dazomet was applied with a drop spreader with a 0.9 m width calibrated to apply $84 \mathrm{~kg} \cdot \mathrm{ha}^{-1}$. Plots were treated with multiple passes of the spreader until the desired rate of application was reached. Following dazomet application, irrigation was applied according to current label requirements, which call for $2.5 \mathrm{~cm}$ of irrigation over a 4-h period the day of application (Anonymous, 2003). Irrigation was applied in decreasing amounts each day for the next $5 \mathrm{~d}$. Irrigation amounts were $1.9,1.25,0.6,0.3$, and $0.3 \mathrm{~cm}$ at $1,2,3$, 4 , and 5 DAT, respectively. Each main plot was then divided into $0.9 \times 0.6-\mathrm{m}$ subplots for bentgrass seeding. At the Indiana location, each subplot was power raked to prepare the seedbed and $5 \mathrm{~g} \cdot \mathrm{m}^{-2}$ of 'Penneagle' creeping bentgrass was applied with a shaker jar. At the Illinois location, $5 \mathrm{~g} \cdot \mathrm{m}^{-2}$ of 'SR1020' and 'Providence' creeping bentgrasses were sliced into the soil using a Jacobsen overseeder. Subplots were seeded at 5, 7, and 9 DAT in 2000. In May 2001, subplots were seeded at 3, 5, 7, and 9 DAT, whereas subplots were seeded at 0, 1, 3, 5, 7, and 9 DAT in August 2001. One subplot in each main plot was left unseeded to facilitate core sampling for $\mathrm{AB}$ seed viability determinations.

Data collection and analysis. After turfgrass establishment reached $100 \%$ cover, each plot was rated visually for percent $\mathrm{AB}$ infestation. Only main plot ratings for establishment were collected for studies conducted in 2000 at Illinois. Based on the large differences observed between subplot treatments, subplots were rated separately at Illinois in 2001 and subplot data were recorded in all trials in Indiana. Coverage and establishment data were analyzed as a split plot with dazomet treatment as the main plot and bentgrass seeding date as the split plot. Regression analysis was conducted on all dazomet rate trials.

At 7 DAT, two 10-cm-diameter cores were removed from each unseeded subplot and sectioned into depths of 0 to 1,1 to 2 , and 2 to 3 $\mathrm{cm}$ with the 0 depth defined as the beginning of the thatch/mat layer. The two core sections from the same depth interval were combined and air-dried (Indiana) or dried in a forced air oven at $45^{\circ} \mathrm{C}$ (Illinois). Following drying, the samples were ground, weighed, and a $10-\mathrm{g}$ subsample (0 to $1 \mathrm{~cm}$ depth) or 30 -g subsample (1 to 2 and 2 to $3 \mathrm{~cm}$ depths) removed for $\mathrm{AB}$ soil seed bank determination. Soil subsamples were topdressed onto $230-\mathrm{cm}^{2}$ plastic flats filled with sterilized greenhouse soil (1 perlite : 1 soil $: 1$ sand, by volume), placed under a mist bench, and irrigated six times daily for 4 weeks. The number of $\mathrm{AB}$ seedlings was counted as an estimate of viable $A B$ seeds in the original sample. Smaller soil samples were used for the 0 to $1 \mathrm{~cm}$ depth because the large number of viable seed made counting difficult. Data for the Fall 2000 trials in Illinois were lost because drying oven temperatures were too high, killing the seed. $\mathrm{AB}$ seed germination data were analyzed as a split plot with dazomet rate as the main plot and sample depth as the split plot. All statistical analyses were conducted using SuperAnova statistical software package (Abacus Concepts, Berkeley, Calif.).

\section{Results and Discussion}

\section{Poa annua establishment}

Application rate studies. All four fall rate trials produced significant $(P>0.1)$ dazomet rate responses for $\mathrm{AB}$ establishment (Tables
1-4), while only two of the four spring trials produced significant rate effects. Regression analysis of the fall trials yielded a highly significant linear rate response in all four trials (Table 5). Both fall Indiana trials also had a significant quadratic response that resulted from less consistent control at the highest dazometrate (Table 5). There were no significant interactions between dazomet rate and seeding date, and so individual seeding date by dazomet rate data are not shown. In general, dazomet applied at $\geq 420 \mathrm{~kg} \cdot \mathrm{ha}^{-1}$ consistently produced the lowest amount of $\mathrm{AB}$ reestablishment. Lower rates of dazomet often did not completely control the existing turf, which was predominantly $\mathrm{AB}$. Thus, high levels of $\mathrm{AB}$ in these treatments did not result entirely from $A B$ seed germination, but also from survival of the original turf. Dazomet control in the spring was generally erratic, and high rates of dazomet in the spring did not provide consistently low levels of $\mathrm{AB}$ reestablishment.

Application method studies. The various applications methods had little influence on dazomet efficacy (Tables 6-9). Spring 2000 trials at both locations produced high levels of $\mathrm{AB}$ establishment regardless of treatment. Spring 2001 studies showed dramatically better results with the Indiana trial yielding almost no $\mathrm{AB}$ establishment with or without dazomet. The Spring 2001 Illinois trial had reasonable $\mathrm{AB}$ control where dazomet was applied (AB populations from $4 \%$ to $27 \%$ ) while the glyphosate plus diquat control treatment was almost completely covered with $\mathrm{AB}$.

The fall studies also produced variable results. Since dazomet at $420 \mathrm{~kg} \cdot \mathrm{ha}^{-1}$ and higher produced the best results in the rate studies, the

Table 1. Effectiveness of dazomet rates applied before creeping bentgrass seeding as measured by reestablishment of annual bluegrass in Indiana. Influence of dazomet rate on the visual estimation of percent annual bluegrass cover.

\begin{tabular}{lccccc}
\hline $\begin{array}{l}\text { Treatment } \\
\text { (kg a.i./ha) }\end{array}$ & Rate & Spring & Fall & Spring & Fall \\
\hline Glyphosate + diquat & $2.24+0.28$ & 76 & 2000 & 2001 & 2001 \\
Dazomet & $168^{\mathrm{y}}$ & 92 & $37 \mathrm{~d}^{\mathrm{z}}$ & $1 \mathrm{a}$ & $41 \mathrm{c}$ \\
Dazomet & 252 & 95 & $4 \mathrm{c} c$ & $23 \mathrm{~b}$ & $10 \mathrm{ab}$ \\
Dazomet & 336 & 74 & $21 \mathrm{~b}$ & $20 \mathrm{~b}$ \\
Dazomet & 420 & 66 & $1 \mathrm{ab}$ & $14 \mathrm{~b}$ & $6 \mathrm{a}$ \\
Dazomet & 504 & 59 & $2 \mathrm{a}$ & $2 \mathrm{a}$ & $9 \mathrm{ab}$ \\
Significance & & NS & $* * *$ & $20 \mathrm{~b}$ \\
\hline
\end{tabular}

${ }^{2}$ Within columns, means followed by the same letter are not significantly different according to Fisher's protected LSD (0.05).

${ }^{y}$ Rates were uniformly reduced by $28 \mathrm{~kg} \cdot \mathrm{ha}^{-1}$ in the Spring 2000 trials.

NS,*,****Nonsignificant or significant at $P=0.05,0.01$, or 0.001 , respectively. ANOVA and LSD values are determined with arc-sin-transformed data; however, means are reported as percent annual bluegrass cover.

Table 2. Effect of interval between dazomet application and bentgrass seeding on the percent annual bluegrass reestablishment in Indiana. Annual bluegrass cover estimated visually.

\begin{tabular}{lcccc}
\hline $\begin{array}{l}\text { Seeding interval } \\
(\mathrm{d})\end{array}$ & $\begin{array}{c}\text { Spring } \\
2000\end{array}$ & Fall & Spring & Fall \\
\hline 0 & ---- & 2000 & 2001 & 2001 \\
1 & --- & --- & --- & $16 \mathrm{ab}$ \\
3 & --- & --- & 13 & $7 \mathrm{a}$ \\
5 & $66 \mathrm{a}^{\mathrm{z}}$ & --- & 11 & $22 \mathrm{~b}$ \\
7 & $78 \mathrm{~b}$ & 9 & 9 & $18 \mathrm{~b}$ \\
9 & $86 \mathrm{c}$ & 7 & 8 & $32 \mathrm{c}$ \\
Significance & $* * *$ & 11 & NS & $* * *$ \\
\hline
\end{tabular}

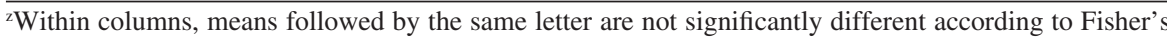
protected LSD (0.05).

NS,***,**Nonsignificant or significant at $P=0.05,0.01$, or 0.001 , respectively. ANOVA and LSD values are determined with arc-sin-transformed data; however, means are reported as percent annual bluegrass cover. 
Table 3. Effectiveness of dazomet rates applied before creeping bentgrass seeding as measured by reestablishment of annual bluegrass in Illinois. Influence of dazomet rate on the visual estimate of percent annual bluegrass cover.

\begin{tabular}{|c|c|c|c|c|c|}
\hline $\begin{array}{l}\text { Treatment } \\
\text { (kg a.i./ha) }\end{array}$ & Rate & $\begin{array}{c}\text { Spring } \\
2000\end{array}$ & $\begin{array}{c}\text { Fall } \\
2000\end{array}$ & $\begin{array}{c}\text { Spring } \\
2001\end{array}$ & $\begin{array}{c}\text { Fall } \\
2001\end{array}$ \\
\hline Glyphosate + diquat & $2.24+0.28$ & $30 \mathrm{a}^{\mathrm{z}}$ & 17 & $87 \mathrm{bc}$ & $24 \mathrm{ab}$ \\
\hline Dazomet & $168^{+}$ & $80 \mathrm{c}$ & 18 & $82 \mathrm{c}$ & $88 \mathrm{c}$ \\
\hline Dazomet & 252 & $55 \mathrm{~b}$ & 17 & $55 \mathrm{ab}$ & $76 \mathrm{c}$ \\
\hline Dazomet & 336 & $42 \mathrm{ab}$ & 13 & $25 \mathrm{a}$ & $44 \mathrm{~b}$ \\
\hline Dazomet & 420 & $23 \mathrm{a}$ & 3 & $11 \mathrm{a}$ & $14 \mathrm{a}$ \\
\hline Dazomet & 504 & $33 \mathrm{ab}$ & 2 & $8 a$ & $11 \mathrm{a}$ \\
\hline Significance & & $* *$ & $* * * *$ & $* * *$ & $* * *$ \\
\hline
\end{tabular}

${ }^{2}$ Within columns, means followed by the same letter are not significantly different according to Fisher's protected LSD (0.05)

${ }^{y}$ Rates were uniformly reduced by $28 \mathrm{~kg} \cdot \mathrm{ha}^{-1}$ in the Spring 2000 trials

${ }^{* *, * * *, * * * *}$ Significant at $P=0.05,0.01$, or 0.001 , respectively. ANOVA and LSD values are determined with arc-sin-transformed data; however, means are reported as percent annual bluegrass cover.

Table 4. Effect of interval between dazomet application and bentgrass seeding on the percent annual bluegrass reestablishment in Illinois. Annual bluegrass cover estimated visually.

\begin{tabular}{lcc}
\hline $\begin{array}{l}\text { Seeding interval } \\
(\mathrm{d})\end{array}$ & $\begin{array}{c}\text { Spring } \\
2001\end{array}$ & $\begin{array}{c}\text { Fall } \\
2001\end{array}$ \\
\hline 0 & --- & $36 \mathrm{~b}$ \\
1 & --- & $29 \mathrm{a}$ \\
3 & $37 \mathrm{a}$ & $36 \mathrm{ab}$ \\
5 & $44 \mathrm{ab}$ & $47 \mathrm{c}$ \\
7 & $47 \mathrm{ab}$ & $56 \mathrm{~d}$ \\
9 & $51 \mathrm{~b}$ & $54 \mathrm{~d}$ \\
Significance & $* *$ & $* * *$ \\
\hline
\end{tabular}

${ }^{\mathrm{z}}$ Within columns, means followed by the same letter are not significantly different according to Fisher's protected LSD (0.05).

${ }^{y}$ Rates were uniformly reduced by $28 \mathrm{~kg} \cdot \mathrm{ha}^{-1}$ in the Spring 2000 trials.

Significant at $P=0.05,0.01$, or 0.001 , respectively. ANOVA and LSD values are determined with arc-sin-transformed data; however, means are reported as percent annual bluegrass cover.

$336 \mathrm{~kg} \cdot \mathrm{ha}^{-1}$ rate used in the application method studies may have been too low to provide consistent $\mathrm{AB}$ control. Regardless of dazomet rate, dazomet incorporation via aerification before or after application does not significantly improve control. Though a simple application of dazomet will be effective, aerification to improve seedsoil contact will improve germination and establishment of the newly seeded turfgass.

Effect of reseeding interval. Both the dazomet rate and methods of application trials were overseeded with creeping bentgrass at various intervals following dazomet application. The seeding date subplots showed significant differences in $\mathrm{AB}$ reestablishment in eight of twelve trials where subplot data were collected (Tables 2, 4, 7, and 9). In the 2000 studies, seeding treatments were made at 5,7 , or $9 \mathrm{~d}$ after dazomet application (DAT) to allow time for dazomet residues to dissipate. However, no negative impact on bentgrass seeded at day 5 was observed, so in Spring 2001 seeding interval was shortened to 3 DAT. Bentgrass seeded at 3 DAT was similarly unaffected by dazomet residues. In Fall 2001, seeding intervals were changed to 0 (seed applied immediately before dazomet application), 1, 3, 5, 7, and 9 DAT. When the seeding interval was shortened to 0 DAT, seeding interval and dazomet rate were significant factors in the regression analysis of the rate trials (Table 5). For each day of delay in reseeding following dazomet application, a $2.0 \%$ to $2.8 \%$ increase in $\mathrm{AB}$ reestablishment was observed. The lowest level of $\mathrm{AB}$ infestation, $4 \%$ (average of both locations), was observed when bentgrass was seeded $1 \mathrm{~d}$ after application of $504 \mathrm{~kg} \cdot \mathrm{ha}^{-1}$ dazomet in Fall 2001

Surprisingly, bentgrass was not killed even when seeded 0 DAT. Bentgrass seed sown at 0 DAT appeared stunted when compared to the seed planted at 1 DAT, but the stunting disappeared within 2 weeks and normal establishment followed. The reduction in establishment vigor of seed planted the day of dazomet application may explain the consistently higher levels of $\mathrm{AB}$ contamination in the 0 DAT seeding (Tables 2 , 4,7 , and 9). Based on both the application methods and dazomet rate trials, optimum bentgrass establishment and minimum AB infestation will be obtained when bentgrass is seeded between 1 and $3 \mathrm{~d}$ after dazomet application (Tables 2, 4,7 , and 9).

\section{Control of the Poa annua soil seed bank}

Individual data are not presented due to the extreme variability found with this analysis technique. However, three important points can be gleaned from the data. The most consistent finding was that viable $\mathrm{AB}$ seed decreased significantly $(P=0.001)$ in every trial with depth (Table 10). On average, $80 \%$ of the viable AB seed was in the 0 to $1-\mathrm{cm}$ layer. A sod producer who has fields infested with $\mathrm{AB}$ could remove a majority of the soil seed bank by simply harvesting a thicker cut of sod. Furthermore, incorporating a soil sterilant like dazomet in only the top $1.0 \mathrm{~cm}$ of the soil profile will control the majority of the $\mathrm{AB}$ seed and incorporating a sterilant much deeper than that will not significantly improve control.

Second, the average reduction in viable $\mathrm{AB}$ seed was $66 \%$ and $62 \%$ for the 420 and 505 reestablishment.

NSNonsignificant. $\mathrm{kg} \cdot \mathrm{ha}^{-1}$ dazomet rates, respectively. When only the fall trials were considered, the reduction in viable $\mathrm{AB}$ seed rose to $86 \%$ and $85 \%$ for the 420 and $505 \mathrm{~kg} \cdot \mathrm{ha}^{-1}$ rates. Even under the best conditions, fall applications at high rates, $<90 \%$ control was obtained. If care and diligence are not utilized, the overseeding will be reinfested with $\mathrm{AB}$, and points to the necessity of seeding quickly after dazomet application and getting full bentgrass cover as soon as possible to minimize subsequent reinfestation,

Third, these data help confirm the observations of Lush (1988) and Wu et al. (1987) regarding the germination characteristics of $A B$ seed.Lush (1988) observed that most of the seed shed in the spring germinated throughout the spring and summer and that long-term dormancy of $\mathrm{AB}$ seed was provided by a relatively small population of the total seed production. Our data showed $>2.2$ times as many viable $\mathrm{AB}$ seeds in the spring than in the following late summer period, indicating that much of the seed shed in the spring of the year is readily viable and has largely germinated by late summer. Trying to establish a bentgrass turf in the spring will result in tremendous competition from germinating $\mathrm{AB}$. One might be tempted to use a soil sterilant in the spring, but as this research has shown, it is best to allow the spring germination to run its course and attempt renovation in the late summer.

As observed by Park and Landschoot (2002), dazomet does not control all viable $\mathrm{AB}$ seed in the soil. Indeed, whereas Park and Landschoot reported control of $>90 \%$ at rates of $340 \mathrm{~kg} \cdot \mathrm{ha}^{-1}$ or higher, we saw much more variable rates of control of the AB soil seed bank. Park and Landschoot counted the number of AB seedlings that emerged in the treated plots within the first three weeks following dazomet application. Our approach was to collect soil samples at 7 DAT, dry the samples, and measure germination within 2 to 6 months following sample collection. Neither approach can completely estimate the soil seed bank, because some dormant, viable seed may not germinate in the relatively short time allowed for germination by both investigators. However, the more variable results and less overall control observed in our studies may be explained by the additional time between dazomet application and the estimation of $A B$ seed viability. Our seeding interval data (Tables $1-4,6-7$, and 9) indicates that $A B$ germination can increase within weeks following dazomet application.

Spring dazomet applications did not work well, failing completely at both locations in 2000, providing good results at Indiana in

Table 5. Regression analysis of the effect of dazomet application rate on the amount of annual bluegrass

\begin{tabular}{llc}
\hline Trial year and location & Regression equation & Significance \\
\hline Spring 2000 Illinois & & NS \\
Spring 2000 Indiana & $\% \mathrm{AB}=21-0.034 \times$ rate & NS \\
Fall 2000 Illinois & $\% \mathrm{AB}=36-0.191 \times$ rate $+0.00025 \times$ rate $^{2}$ & $P<0.05$ \\
Fall 2000 Indiana & $\% \mathrm{AB}=94.8-0.175 \times$ rate & $P<0.0001$ \\
Spring 2001 Illinois & $\% \mathrm{AB}=37.2-0.075 \times$ rate & $P<0.0001$ \\
Spring 2001 Indiana & $\% \mathrm{AB}=121-0.256 \times$ rate $+2.8 \times$ seed date & $P<0.0001$ \\
Fall 2001 Illinois & $\% \mathrm{AB}=31.8-0.193 \times$ rate $+0.0003 *$ rate $^{2}+2.03 \times$ seed date & $P<0.0001$ \\
\hline Fall 2001 Indiana &
\end{tabular}


Table 6. Effect of application method on dazomet before creeping bentgrass establishment as measured by the reestablishment of annual bluegrass in Indiana. Influence of soil preparation methods on the visual estimate of percent annual bluegrass cover.

\begin{tabular}{lccccc}
\hline & & Spring & Fall & Spring & Fall \\
Treatment & Rate & 2000 & 2000 & 2001 & 2001 \\
\hline Glyphosate + diquat & $2.24+0.28$ & 88 & $53 \mathrm{~b}^{\mathrm{z}}$ & 3 & $29 \mathrm{~b}$ \\
Dazomet, no soil treatment & $336^{\mathrm{y}}$ & 87 & $11 \mathrm{a}$ & 0.5 & $4 \mathrm{a}$ \\
Aerify 1× before dazomet app & 336 & 88 & $6 \mathrm{a}$ & 0 & $4 \mathrm{a}$ \\
Aerify 3× before dazomet app & 336 & --- & $4 \mathrm{a}$ & 0 & $5 \mathrm{a}$ \\
Aerify 1× after dazomet app & 336 & 84 & $8 \mathrm{a}$ & 1 & $6 \mathrm{a}$ \\
Aerify 3× after dazomet app & 336 & -- & $3 \mathrm{a}$ & 0 & $6 \mathrm{a}$ \\
Aerify 1×, remove cores, dazomet app & 336 & --- & & 0 & $3 \mathrm{a}$ \\
Aerify 3×, remove cores, dazomet app & 336 & --- & & 1 & $5 \mathrm{a}$ \\
Significance & & NS & $*$ & NS & $* * *$ \\
\hline
\end{tabular}

${ }^{2}$ Within columns, means followed by the same letter are not significantly different according to Fisher's protected LSD (0.05).

${ }^{y}$ Dazomet rate was $308 \mathrm{~kg} \cdot \mathrm{ha}^{-1}$ in the Spring 2000 trials.

NS, ,**,**** Nonsignificant or significant at $P=0.05,0.01$, or 0.001 , respectively. ANOVA and LSD values are determined with arc-sin-transformed data; however, means are reported as percent annual bluegrass cover.

Table 7. Effect of interval between dazomet application and bentgrass seeding on the percent annual bluegrass reestablishment in Indiana. Annual bluegrass cover estimated visually.

\begin{tabular}{lcccc}
\hline $\begin{array}{l}\text { Seeding interval } \\
\text { (d after transplanting) }\end{array}$ & $\begin{array}{c}\text { Spring } \\
2000\end{array}$ & $\begin{array}{c}\text { Fall } \\
2000\end{array}$ & $\begin{array}{c}\text { Spring } \\
2001\end{array}$ & $\begin{array}{c}\text { Fall } \\
2001\end{array}$ \\
\hline 0 & --- & --- & --- & $12 \mathrm{~d}$ \\
1 & --- & --- & --- & $5 \mathrm{a}^{2}$ \\
3 & --- & --- & $0 \mathrm{a}$ & $5 \mathrm{a}$ \\
5 & $79 \mathrm{a}$ & 13 & $0.5 \mathrm{a}$ & $7 \mathrm{ab}$ \\
7 & $90 \mathrm{~b}$ & 14 & $0.5 \mathrm{a}$ & $9 \mathrm{bc}$ \\
9 & $93 \mathrm{~b}$ & 15 & $2 \mathrm{~b}$ & $10 \mathrm{~cd}$
\end{tabular}

${ }^{2}$ Within columns, means followed by the same letter are not significantly different according to Fisher's protected LSD (0.05).

NS,*,**,***N Nonsignificant or significant at $P=0.05,0.01$, or 0.001 , respectively. ANOVA and LSD values are determined with arc-sin-transformed data; however, means are reported as percent annual bluegrass cover.

Table 8. Influence of soil preparation techniques on dazomet effectiveness as measured using the visual estimate of percent annual bluegrass cover reestablishment in Illinois.

\begin{tabular}{lccccc}
\hline & & Spring & Fall & Spring & Fall \\
Treatment & Rate & 2000 & 2000 & 2001 & 2001 \\
\hline Glyphosate + diquat & $2.24+0.28$ & 33 & 32 & $97 \mathrm{a}^{\mathrm{z}}$ & 18 \\
Dazomet, no soil treatment & $336^{\mathrm{y}}$ & 53 & 48 & $21 \mathrm{~b}$ & 29 \\
Aerify 1× before dazomet app & 336 & 72 & 42 & $19 \mathrm{~b}$ & 61 \\
Aerify 3× before dazomet app & 336 & --- & 30 & $15 \mathrm{~b}$ & 30 \\
Aerify 1× after dazomet app & 336 & 57 & 28 & $24 \mathrm{~b}$ & 47 \\
Aerify 3× after dazomet app & 336 & --- & 25 & $27 \mathrm{~b}$ & 38 \\
Aerify 1×, remove cores, dazomet app & 336 & --- & & $16 \mathrm{~b}$ & 30 \\
Aerify 3×, remove cores, dazomet app & 336 & --- & & $4 \mathrm{~b}$ & 20 \\
Significance & & NS & NS & $* * *$ & NS \\
\hline
\end{tabular}

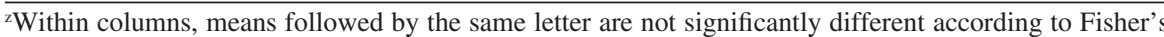
protected LSD (0.05).

${ }^{y}$ Dazomet rate was $308 \mathrm{~kg} \cdot \mathrm{ha}^{-1}$ in the Spring 2000 trials.

NS, ,**,****Nonsignificant or significant at $P=0.05,0.01$, or 0.001 , respectively. ANOVA and LSD values are determined with arc-sin-transformed data; however, means are reported as percent annual bluegrass cover.

Table 9. Effect of interval between dazomet application and bentgrass seeding on the percent annual bluegrass reestablishment in Illinois. Annual bluegrass cover estimated visually.

\begin{tabular}{lcc}
\hline $\begin{array}{l}\text { Seeding interval } \\
\text { (d after transplanting) }\end{array}$ & $\begin{array}{c}\text { Spring } \\
2001\end{array}$ & $\begin{array}{c}\text { Fall } \\
2001\end{array}$ \\
\hline 0 & & $33 \mathrm{c}^{\mathrm{z}}$ \\
1 & & $13 \mathrm{a}$ \\
3 & 27 & $19 \mathrm{ab}$ \\
5 & 29 & $27 \mathrm{bc}$ \\
7 & 29 & $50 \mathrm{~d}$ \\
9 & 30 & $62 \mathrm{e}$ \\
Significance & NS & $* * *$ \\
\hline
\end{tabular}

${ }^{\mathrm{z}}$ Within columns, means followed by the same letter are not significantly different according to Fisher's protected LSD (0.05).

NS,*,******Nonsignificant or significant at $P=0.05$, 0.01 , or 0.001 , respectively. ANOVA and LSD values are determined with arc-sin-transformed data; however, means are reported as percent annual bluegrass cover. provide good results, one exception was the Spring 2001 trial at Indiana (Tables 1-2 and 6-7). In the dazomet rate trial, low levels of $\mathrm{AB}$ reestablishment were observed across all treatments, and in particular in the non-selective herbicidal control treatment and the two highest dazomet rates. The herbicidal control treatment had only $1 \%$ AB cover(Table 1-2), however, the soil seed bank data (data not shown) indicated that the control treatment had the highest level of viable $\mathrm{AB}$ seeds. The lack of establishment even with high levels of $A B$ seeds in the soil is most likely due to unfavorable temperatures that inhibit AB germination. Henry et al. (2002) observed this same response when they found that summer-seeded bentgrass produced turf with lower levels of $\mathrm{AB}$ reestablishment than when seeded at the more optimal times for turfgrass establishment.

We also observed that $\mathrm{AB}$ invasion into the new turf would increase if seeding were not completed by three days after dazomet application. Dazomet does not eradicate $\mathrm{AB}$ seed from the soil, rather it helps create an $\mathrm{AB}$-free window of seeding opportunity. Most of the $A B$ seed that is capable of germinating readily has been killed by the dazomet application, but a larger reservoir exists and the longer the interval between dazomet application and bentgrass seeding, the more likely that $\mathrm{AB}$ will be able to reinfest the turf.

This research shows that dazomet can be helpful in establishing turf with minimal amounts of $\mathrm{AB}$ present in the resulting stand. However, environmental conditions, i.e., wind, may dramatically affect the level of control observed. Furthermore, while the AB soil seed bank is reduced by dazomet application, it is not eliminated and additional, postestablishment control strategies will have to be implemented to keep $\mathrm{AB}$ from reinfesting the new turf over time.

\section{Literature Cited}

Anonymous. 2003. Basamid granular. http://www. basf.de/en/produkte/gesundheit/pflanzen/products/basamid/labels.

Beard,J.B.,P.E. Rieke, A.J. Turgeon, and J.M. Vargas, Jr. 1978. Annualbluegrass (Poa annua L.) description, adaptation, culture, and control. Mich. State Univ. Agr. Expt. Sta. Res. Rpt. 352.

Gaussoin, R.E. and B.E. Branham. 1989. Influence of cultural factors on species dominance in a mixed stand of annual bluegrass/creeping bentgrass. Crop Sci. 29:480-484.

Henry, G.M., S.E. Hart, and J.A. Murphy. 2002. Overseeding bentgrass species into existing stands of Poa annua. Proc NEWSS. 56:113.

Locascio, S.J., J.P. Gilreath, D.W. Dickson, T.A. Kucharek, J.P. Jones, and J.W. Noling. 1997. Fumigant alternatives to methyl bromide for polyethylene-mulched tomato. HortScience 32:1208-1211.

Low, A.J. 1974. The use of dazomet for partial sterilization of forest nursery soils. Forestry 47:31-43.

Lush, W.M. 1988. Biology of Poa annua in a temperature zone golf putting green (Agrostis stolonifera/Poa annua) II. The seed bank. J. Appl. Ecol. 25:989-997.

Park, B.S. and P.J. Landschoot. 2003. Effect of dazomet on annual bluegrass emergence and creeping bentgrass establishment in turf 
Table 10. Mean squares from the analysis of variance for the square root transformed number of viable annual bluegrass seed remaining following treatment with various dazomet application rates.

\begin{tabular}{|c|c|c|c|c|c|c|c|c|}
\hline \multirow[b]{2}{*}{ Source } & \multirow[b]{2}{*}{ df } & \multicolumn{2}{|c|}{$\begin{array}{c}\text { Spring } \\
2000\end{array}$} & \multirow{2}{*}{$\begin{array}{c}\text { Fall } \\
2000 \\
\mathrm{PU}\end{array}$} & \multicolumn{2}{|c|}{$\begin{array}{c}\text { Spring } \\
2001\end{array}$} & \multicolumn{2}{|c|}{$\begin{array}{l}\text { Fall } \\
2001\end{array}$} \\
\hline & & IL & $\mathrm{PU}$ & & IL & $\mathrm{PU}$ & IL & $\mathrm{PU}$ \\
\hline$\overline{\text { Dazomet rate }(\mathrm{R})}$ & 5 & 143 & $35.0^{*}$ & $69.9^{* * *}$ & 34.0 & 86.0 & 6.0 & $40.4^{*}$ \\
\hline Depth (D) & 2 & $5612^{* * * *}$ & $1460^{* * * *}$ & $87.6^{* * *}$ & $232^{* * * *}$ & $1970^{\text {***** }}$ & $53.8^{* *}$ & $242^{* * * *}$ \\
\hline $\mathrm{R} \times \mathrm{D}$ & 10 & 84.7 & 16.0 & $10.3^{*}$ & 1.4 & 15.2 & 4.4 & 15.3 \\
\hline
\end{tabular}

${ }_{*, * * * * * *}$ Significant at $P=0.05,0.01$, or 0.001 , respectively

maintained as a golf course fairway. Crop Sci. 43:1387-1394.

Rieger, M., G. Krewer, and P. Lewis. 2001. Solarization and chemical alternatives to methyl bromide for preplant soil treatment of strawberries. HortTechnology 11:258-264.

Smelt, J.H. and M. Leistra. 1974. Conversion of metham-sodium to methyl isothiocyanate and the basic data on the behavior of methyl isothiocyanate in soil. Pest. Sci. 5:401-407.
Turgeon, A.J. 2002. Turfgrass management. Prentice Hall, Upper Saddle River, N.J.

Unruh, J.B., B.J. Brecke, J.A. Dusky, and J.S. Godbehere. Fumigant alternatives for methyl bromide prior to turfgrass establishment. Weed Technol. 16:379-387.

Wu, L., I. Till-Bottraud, and A. Torres. 1987. Genetic differentiation in temperature-enforced seed dormancy among golf course populations of $\mathrm{Poa}$ annua L. New Phytol. 107:623-631. 